\title{
ResearchGate
}

See discussions, stats, and author profiles for this publication at:

https://www.researchgate.net/publication/257557763

\section{How International Relations Theorists Can Benefit by Reading Thucydides}

Article in The Monist · April 2006

DOI: $10.2307 / 27903977$

CITATIONS

READS

2

293

1 author:

\section{W. Julian Korab-Karpowicz}

Lazarski University

17 PUBLICATIONS 7 CITATIONS

SEE PROFILE

Some of the authors of this publication are also working on these related projects:

Project Philosophy and Myth View project

Project Heidegger View project 


\section{How InTERnATIONAL RELATIONS THEORISTS CAN BENEFIT By READING THUCYDIDES}

Often regarded as the father of realism in international relations, Thucydides was a historian and an original political thinker who described and analyzed social and political events that occurred during the Peloponnesian War, which broke out in 431 B.c. between Athens and Sparta. Thucydides' masterpiece, the History of the Peloponnesian War is not a work of political philosophy nor a sustained theory of international politics. Much of the History consists of paired speeches by personages who argue both sides of an issue. In these speeches and in Thucydides' own comments on the events that take place, we can catch a glimpse of a theory that is implied, but nowhere fully formulated or made explicit. Although Thucydides implies that he exemplifies universal truths about human nature, civil society, and interstate relationships, he does not present this point of view explicitly, and never engages with other thinkers in a debate. ${ }^{1}$ Nevertheless, if the .History is described as the only acknowledged classical text in international relations, and if it inspires theorists from Hobbes to contemporary international relations scholars, this is because it is more than a chronicle of events, and a theoretical position can be extrapolated from it.

The History of the Peloponnesian War is usually seen as an archetypal statement of power politics. Thucydides is regarded as a political realist who asserts that the pursuit of moral principles does not enter the world of international affairs. ${ }^{2}$ I want to show that, on the contrary, we find in Thucydides a complex theory. He supports neither extreme realism, in which international morality is denied, nor utopian idealism that overlooks the aspect of power in international relations. He is profoundly interested in ethical issues in domestic and international politics. Against the provocative title of the recent article of David Welch, "Why International Relations Theorists Should Stop Reading Thucydides,"3 I 
argue that both theorists and practitioners of international politics should read Thucydides, and can greatly benefit by reading him.

\section{Thucydides' Realism}

The task that Thucydides sets for himself is not just to describe the harsh events that occurred during the Peloponnesian War "and will always happen as long as human nature remains the same" (3.82.2). ${ }^{4}$ As he says on its opening pages, the History is not a piece of writing designed to meet the taste of the immediate public, but is meant to last forever. He is not merely interested in reconstructing historical events, using the best evidence available, but in providing their general explanation. His work is essentially a study of human and state behavior, in which a theory is implied and permanent characteristics of human affairs and international politics are revealed. Because of his pessimism about human nature, his emphasis on power, and his recognition that morality has little place in inter-state relations, he is often credited with being the first writer in the tradition of political realism. ${ }^{5}$

What is realism? Realism is a view of international politics that stresses its competitive and conflicting side. ${ }^{6}$ The principal actors in the international arena are states that are concerned with their own security, act in pursuit of their national interests, and struggle for power. Thucydides seems to subscribe to this view. Distinguishing between immediate and underlying causes of the Peloponnesian War, he does not see its underlying cause in the Athenian intervention in the conflict between Corcyra and Corinth, her siege of Potidaea, or her ban on trade with Megara - the events that occurred immediately before its outbreak. He locates the root of the war in the changing distribution of power between the two blocks of Greek city-states: the Delian League and the Peloponnesian League. According to him, the growth of Athenian power made the Spartans fear for their security, and thus compelled them into war (1.23.6). What he says resonates strongly with realist arguments on how the anarchic structure of the international system affects the behavior of states. The realists find the absence of a ruler, literally anarchy, the defining element of international politics and primary determinant of international political outcomes. The lack of a rule-making and enforcing common authority means, they claim, that each state is responsible for its survival and is free to define its own power interests. In the worlds of the 
Athenian envoys at Melos, if there is no international government that can enforce order, "the independent states survive [only] when they are powerful" (5.97.2). International anarchy leads thus to the overriding role of power in inter-state relations and causes all states to be motivated by fear and mutual distrust. To attain security, states increase their relative power and engage in power balancing for the purpose of deterring potential aggressors. Wars are fought to prevent any competing nations from becoming militarily stronger.

The negative side of this emphasis on power is the realists' skepticism regarding the applicability of universal ethical norms to relations among states. National politics is the realm of authority and law, whereas international politics, unrestrained by any higher moral laws, is a sphere without justice characterized by active or potential conflict between states. A confirmation of this position can again be found in the "Melian Dialogue" (5.85-113). This dialogue relates to the events of 416 B.C., when Athens invaded the neutral island of Melos. The Athenian envoys present the Melians with a choice between destruction or surrender, and from the outset ask them not to appeal to justice, but to think about their survival. They say: "We both know that the decisions about justice are made in human discussions only when both sides are under equal compulsion, but when one side is stronger, it gets as much as it can, and the weak must accept that" (5.89). To be "under equal compulsion" means to be subjected to a common authority. Since such an authority above states does not exist, the Athenians argue that the only right in the world of anarchy is the right of the stronger to dominate the weaker. They explicitly equate right with might, and exclude considerations of justice from foreign affairs. Further, the right of the stronger to dominate is for them a natural law. "Nature always compels gods (we believe) and men (we are certain) to rule over anyone they can control" (5.105.2). Hence, in the Athenian speech there is implied not only a denial of international morals, but also a certain view of humankind that is essential for the realist view of international politics. International anarchy would not lead to conflict between nations if they were all populated by angels. Whether explicitly, as in classical realism, or implicitly, as in neorealism, the realistic theory premises an egoistic human nature. ${ }^{7}$ Human beings are perceived as selfinterested and power-seeking, moved by the drive to dominate others, and not influenced by either compassion or any moral rules. 
Realism is implied in the statements of the Athenian envoys at Melos and in the way Thucydides explains the cause of the Peloponnesian War. Moreover, the same outlook of international politics is expressed in the very first speech given by the Athenians in the History, namely, at the debate at Sparta, just before the outbreak of the war. The Athenians refer to three motives that have led them to obtain and keep their empire: fear, honor, and self-interest $(1.75 .3 ; 1.76 .2)$. A similar motivational triad can be found in Hobbes's Leviathan and in twentieth-century realists. ${ }^{8}$ Nearly all realists place fear at the core of state motivation. Fear is a defensive motive, based on the desire for self-preservation; however, honor and selfinterest, desires for recognition and gain, are fundamentally competitive and acquisitive. These three motives are paralleled in Pericles' "last Speech" as safety, glory, and wealth (2.63-64). Athenian imperialism is thus justified on the grounds of security concerns, recognition, and expediency, but not on moral grounds. Further, the Athenians affirm the priority of power over justice in international relations and provide justification for this. They argue that morality cannot be put ahead of power because as a rule "the weaker are held by the stronger" (1.76.2). No one who can obtain something by power will be deterred not to use it. To believe otherwise, they suggest, would be to mislead oneself about the nature of international politics.

The Athenians give then strong support to a realist position. The question is, however, to what extent the view of Athenian realism coincides with Thucydides' own viewpoint. Is his realism the same as the realism of the Athenian envoys at Melos and of the Athenians at the debate at Sparta? Is he a realist at all? Thucydides' History provides an account of debates between groups and individuals, holding often opposite views. The political discourse that he describes is plural, not single. Although fragments of the "Melian Dialogue" and other parts of the Peloponnesian War support a realist reading, Thucydides' realism cannot be deduced from selected fragments but must be assessed on the basis of the wider context of his book. The "Melian Dialogue" itself provides us with a plurality of contending perspectives.

\section{Realism Versus Idealism in the Melian Dialogue}

Political realism is usually contrasted with idealism or liberalism, a theoretical perspective that puts stress on international norms, interdepen- 
dence between states, and international cooperation. 9 The "Melian Dialogue," which is one of the most frequently commented upon parts of Thucydides' History, presents the classic dilemma between idealist and realist thinking: Can international politics be based on a moral order derived from the principles of peace and justice or will it remain the playground of conflicting national interests and power?

For the Melians, who employ idealistic arguments, the choice is between war and subjection (5.86). They do not wish to lose their freedom, and in spite of the fact that they are militarily weaker than the Athenians, they are prepared to defend themselves $(5.100 ; 5.112)$. They base their arguments on an appeal to justice (5.86), and refuse to concede that justice is a mere matter of expediency, but understand it as a universal moral principle. They associate justice with fairness, and regard the Athenians as unjust $(5.90 ; 5.104)$. Also, they put their trust in alliances and hope for military assistance from their ally, Sparta. They respect the gods and believe in honor, saying that their weakness will be made up by the aid of the gods supporting their just cause and the help of the Spartans, whom they hold to be honorable $(5.104 ; 5.112)$. Hence, in the speech of the Melians one can identify such elements of the idealistic or liberal world view as the beliefs that nations have the right to exercise political independence, states have mutual obligations to one another that they will carry out, and the war of aggression is unjust.

The Athenian response is based on such key realist concepts as security and power, and is informed not by what the world should be but what it is. The Athenians urge the Melians to look at the facts, namely to recognize their military inferiority, to consider the potential consequences of their decision, and to think about their own survival $(5.87 ; 5.101)$. They exclude consideration of justice from their discussion and appeal to the identity of interests. $(5.89 ; 5.91)$. They are concerned about their security and express fear that the independent Melos may endanger them (5.99). They argue that it will be better for both sides if Melos gives in. The Melians will save themselves from ruin and the Athenians will reap profits from them (5.93). Melos will add to the empire and no longer be a potential security threat (5.97). Furthermore, the Athenians describe the honor and justice of the Spartans, to which the Melians refer, as mere hypocrisy that masks the Spartan interests. Considering the Athenian power and the risk of military action, they claim that it is foolish to believe 
Sparta will ever come to help and fight for Melos (5.105; 5.109). They advise the Melians not to be distracted by a false notion of honor, which in the absence of strength can only bring them disaster and the dishonor of defeat, or to depend on mere hopes, but to think only about their own country and how to survive in the present circumstances (5.111).

In spite of these realist arguments, the Melians refuse to submit and decide to fight for their independence. After some initial successes on their part, the Athenian siege succeeds. The Melians pay the highest price for their choice. Melian men of military age are killed. Women and children are sold into slavery. Melos loses statehood after seven hundred years of her history. The island is repopulated by Athenian colonists. This tragic story shows that in the end a theory of international relations "involves the ultimate experience of life and death, national existence and national extinction." 10 It is a practical theory, the theory of survival. In the first recorded debate between idealism and realism, realism is the winner, if not by the strength of arguments, then clearly by the force of the Athenian army. There are, nevertheless, reasons to believe that Thucydides does not accept the "radical realism" advocated by the Athenians at Melos. The Athenians do not act as his mouthpiece. Equally, he does not identify his position with the "utopian idealism" represented by the Melians. Both positions reveal serious theoretical weaknesses.

The Melians put high value on courage and honor, and love their country. They have a sense of justice and respect alliances. They are thus in a sense virtuous people. Some of their values resemble those of the Athenians from the earlier period. In one of his speeches, Pericles, the Athenian leader, who dies in the early stage of the War, says that for people who have a choice, to go to war is always a folly. However, when the choice is either to submit to neighbors or to take on dangers to preserve independence, it is better to fight (2.61.1). Contending that not to resist subjugation would be cowardly and shameful, the Melians make the same choice that Pericles suggests and that the Athenians once made themselves when, displaying great courage, they stood alone against the overwhelming might of Persia (1.73-74). The element that they, nevertheless, lack and that does not allow them to be victorious is what Pericles describes as a "strategy based on reality which affords predictable results" (2.62.5). Although they are courageous, the Melians lack resources and foresight. They are guided more by their hopes than by the evidence at 
hand and prudent calculations. They appeal to justice, which is not listened to, and call for help from outside, which cannot be obtained. Ultimately, they are good and courageous, but politically naïve. The kind of utopian idealism that they display leads, because of their lack of good judgment, foresight, and intelligent planning, to martyrdom: the death of combatants and the extreme suffering of civilians, and in the end to the destruction of their political community. Idealism of those who are unable to survive is for Thucydides of no use, and is reported by him solely as a warning against any future political wishful thinking. All the noble aspirations of the Melians are ruined because they do not take into consideration the actual practice of states and do not make provision for their own security.

The Athenians at Melos reveal themselves as models of rational selfinterested agents. They use available means to realize the objectives that they set out. There is a seemingly powerful realist logic behind the Athenian arguments. Their position, based on security concerns and expediency, possesses rationality, intelligence, and foresight. However, on close examination their logic contains serious flaws. Melos, a relatively weak state, does not pose any real security threat to them. Their slaughter of the Melians is a tragic error. The destruction of Melos does not change the course of the Peloponnesian War, which is lost by Athens a few years later. The Athenians argue that the international world, imperfect as it is, is ruled by the law that the weaker are dominated by the stronger, and therefore, moral values cannot be applied to it. They do not only acknowledge the lack of justice in inter-state relations, but also prescribe to states the way of domination. Their radical realism is not merely descriptive and defensive, but normative and offensive, and can be better termed as realpolitik." On the grounds of the purported lack of universal moral standards in international politics and selfishness of states, the Athenians glorify war and conquest, and act accordingly. They replace moral norms with raison d'état, state's expediency, as the highest norm. However, they do not recognize that self-interest and the rules of might alone cannot provide sufficient basis for a practical theory of international politics. In his History, Thucydides shows that if it is unrestrained by moderation and a sense of justice, power brings about the uncontrolled desire for more power. There are no logical limits to the size of an empire. Drunk with the prospect of glory and gain after they conquer Melos, the Athenians engage 
in the war against Sicily. They do not pay attention to the Melian argument that considerations of justice are useful to all in the longer run (5.90). As they overestimate their strength and finally lose the war, the Athenian selfinterested logic is indeed very short-sighted.

It is utopian to ignore the selfishness of states and be blind to the reality of power in international relations, but it is equally blind to rely on power alone. Thucydides would support neither naïve idealism nor cynical realpolitik. If he can still be regarded as a political realist, his realism is neither realpolitik, in which international morality is denied, nor neorealism, in which moral questions are largely ignored. His realism is neither immoral nor amoral. In his realism, selfishness is recognized, but is not exalted and presented as a value. Moderation and a sense of justice should keep states from becoming too opportunistic in defining and pursuing their interests. Thucydides' realism can be compared to that of Raymond Aron, Reinhold Niebuhr, and Hans Morgenthau, the twentiethcentury classical realists, who, although sensible to the demands of power and national interest, would not deny that political actors on the international scene come under moral judgment. ${ }^{12} \mathrm{He}$ is profoundly engaged in reflecting on ethical issues in domestic and international politics.

\section{Politics and Ethics}

While discussing the violent events that occurred at Corcyra during the civil war (3.82-85), Thucydides attributes the growing wickedness, not only at Corcyra but in the whole Hellenic world, to factionalism and the deterioration of moral uprightness (3.83.1-2). Because it is ridiculed, modesty, the simple virtue found in noble natures, disappears. The excessive desire to rule out of selfishness, greed, and personal ambition prevails (3.82.6). Society becomes divided into two opposing camps. Contending political parties promote their policies under fair-sounding slogans, like "equality for all" or "limited government," pretending thus to serve the public, but in fact they struggle for power without any consideration for justice and the common good (3.82.7). Whatever means to win is used, and both sides commit the most horrible atrocities against one another. People go to every extreme. Oaths are not kept. There is no disrespect for piety. Revenge is admired. There is even a revolution in language. Words take on new meanings (3.82.4-5). Acts of thoughtless aggression are described as courageous. Moderation is held to be a cloak 
for unmanliness. Plotting becomes a justifiable means of defense. Moreover, factionalism turns into the most overwhelming factor. The attributes of being a real man are now partisanship and violent fanaticism. Party membership becomes a stronger tie than that of the family. Those who wish to stay as neutral in the middle are destroyed (3.82.8). No argument is strong enough to convince the sides to terminate their mutual hostility.

The civil war in Corcyra is the paradigm of social disintegration. There are many similarities between the events that take place in Corcyra and the later revolution in Athens that leads to overthrowing democracy and establishing oligarchy (8.65-71). For Thucydides the polis is not an abstract entity that has laws of its own. The state cannot be separated from the human beings composing the society. Even if a state can be regarded as a legal abstraction, it is not the state that makes decisions, but individuals. This is why most of Thucydides' ethical words and phrases are used interchangeably to describe individuals and states. His ethical concerns, far from being an expression of abstract thinking, are related to the actual conditions in which states are found. A virtuous political body depends on good qualities of its individual members, and above all on the quality of its leadership. A bad one is corrupted by vice. The disintegration of society that occurs in both Corcyra and Athens is described by such negative ethical words and phrases as 'injustice', 'selfishness', 'greed', 'disregard for piety', 'faction', 'arrogance', 'envy', 'revenge', 'deceit', 'fear', 'cowardice', and 'cruelty'.13 The laudable characteristics of both individual character and a virtuous society, such as respect for law, tolerance, openness, courage, moderation, justice, foresight, self-control, cautious deliberation, prudence, and fraternity, which we can find in Pericles' "Funeral Oration" (2.35-46), in which he describes the Athenian democracy, are absent.

Pericles' Athens stands in Thucydides' History for the supreme achievements of civilization: material, political, and ethical. By contrast, Athens of the revolution and the oligarchic rule following it, is a model of political and moral decline. In his famous oration, Pericles suggests that the Athenian democracy is a good constitution because it allows the admirable individual and public qualities that he mentions to flourish. $\mathrm{He}$ himself displays such prime qualities of character as moderation, foresight, prudence, good judgment, independence of thought and action, and incorruptibility, and it is during his leadership that Athens reaches the 
peak of its greatness (2.65). Nevertheless, in Pericles' speeches there are also the germs of vice that infect Athens and bring about her downfall. Since it produces immoderate individuals, Thucydides suggests, the excessive love of power in international politics will remove all restraint from domestic politics as well.14 Pericles inspires Athenian imperial ambitions and appeals to glory, which ultimately leads the Athenians to excess (2.62-64). The ancient modesty or simplicity, which can be associated with a certain sense of limit, disappears not only from the Corcyran, but also from the Athenian character. The successors of Pericles do not follow his cautious and intelligent war policy but manage the state for their private ambition and private gain (2.65.7). They are not, like Pericles, leaders of public opinion, but striving for popularity, they form policies to suit the whims of the people, regardless of whether these policies are actually good for the state (2.5.10). Ultimately this results in a terrible defeat of the Athenians in Sicily and the oligarchic revolution that follows.

The contrast that Thucydides expresses between Pericles and his successors, and between the Athens of Pericles and the Athens of revolution, suggests that material and political achievements of society are inseparable from its morals. Politics is not merely a matter of some structural considerations, but is related to ethics. The state of different communities may range from a supremely civilized community, based on virtue, downwards to a society degraded by vice and torn apart by civil strife.

\section{Thucydides' History as "Lasting Possession"}

Thucydides' History was meant by him to be a "lasting possession." It would be erroneous, however, to identify that what he wanted to convey to posterity was a narrow realist theory of international relations. His realism refuses to be confined to the narrow realm of security and power, but takes into account the whole political reality with its ideas, passions, and follies. ${ }^{15}$ He neither denies international morals nor, like today's neorealists, ignores them in the name of pretended scientific objectivity. On the contrary, in the Peloponnesian War, unlike the writings of most realists, we can find a deep reflection on ethics in its relation to politics. In much the same way as a physician who pronounces his diagnosis, Thucydides examines the causes of political disorder and studies the ways in which ethical characteristics of a state, or their lack, affect its condition. ${ }^{16}$ 
Like other ancient Greek writers before and after him, such as Hesiod, Solon, Aeschylus, as well as Plato and Aristotle, he considers the lack of morals to be a serious disease of the polis. In this way he is a part of the Hellenic moral tradition in which Western political philosophy is deeply rooted.

One of the main issues that Thucydides considers is the effect of power when it is not kept within the bounds of moderation and justice in both domestic and international politics. Although he never precisely defines justice, it is clear that this and other ethical concepts are for him neither culturally nor historically relative. The absence of justice as a universal moral value is always lamentable. A society that leaves no room for justice and moderation, that knows no law and no limit, Thucydides concludes, is doomed to fail. Humans are rational actors only in a superficial way. At a deeper level, lacking a sense of justice and moderation, they become fundamentally irrational and their irrationality destroys their understanding of what is expedient for them. They often learn moderation only by defeat. The Athenians finally lose the war because, moved by the love of power alone, they overestimate their strength, develop poor policies, and choose wrong leaders. As numerous other examples from world history can show, ${ }^{17}$ no power is ever immune to such miscalculation.

W. Julian Korab-Karpowicz

Bilkent University

Ankara, Turkey

\section{NOTES}

1. In his work, which can impress us by its depth and attention to detail, Thucydides discusses a number of topics. G. F. Abbot puts this as follows: "Hardly a problem of statesmanship is left untouched. . . . The advantages of the sea power (I.142, 143; II.62), the weakness inherent in the nature of a coalition (I.141), the respective merits of severity and magnanimity towards rebellious subjects (III.39-40; 44-48), and many other questions of perennial interests are discussed with a perspicacity which has never been excelled." See G. F. Abbot, Thucydides: A Study in Historical Reality (New York: Russell \& Russell, 1970), pp. $41-42$.

2. Realists regard Thucydides as the founder of realism and their inspiration. In the collected work entitled Roots of Realism, Thucydides occupies a prominent place among such realists as Machiavelli, Carr, Niebuhr, and Morgenthau. See Benjamin Frankel, ed. Roots of Realism (London: Frank Cass, 1966).

3. See David Welch, "Why International Relations Theorists Should Stop Reading Thucydides," Review of International Studies, 29.3 (2003), p. 301-19. Welch does not 
want us to take the title of his article literally. He is against a strictly realist reading of Thucydides' work, and argues that we should not read into it our own assumptions and biases, or reduce it to a series of banalities.

4. My citations come from Thucydides, On Justice, Power and Human Nature: The Essence of Thucydides' History of the Peloponnesian War, trans. Paul Woodruff (Indianapolis, IN: Hackett, 1993). I follow a standard form of reference (book, section, line).

5. For discussions of Thucydides' realism from different perspectives, see Peter J. Ahrensdorf, "Thucydides' Realistic Critique of Realism," Polity, 30.2 (1997), pp. 231-65. David Boucher, Theories of International Relations: From Thucydides to the Present. (Oxford: Oxford University Press, 1998), pp. 67-89; Michael T. Clark, "Realism Ancient and Modern: Thucydides and International Relations," Political Science and Politics, 26.3 (1993), pp. 491-94; Daniel Garst, "Thucydides and Neorealism," International Studies Quarterly, 33.1 (1989), pp. 3-27; Michael Doyle, "Thucydidean Realism," Review of International Studies, 16.3 (1990), pp. 223-37; Steven Forde, "Varieties of Realism: Thucydides and Machiavelli," Journal of Politics, 54.2 (1992), pp. 372-93; Paul A. Rahe, "Thucydides' Critique of Realpolitik," Security Studies, 5 (1995), pp. 105-41.

6. See Jack Donnelly, Realism and International Relations (Cambridge: Cambridge University Press, 2000); Robert G. Gilpin, "The Richness of the Tradition of Political Realism," Neorealism and Its Critics, ed. Robert O. Keohane (New York: Columbia University Press, 1986), pp. 301-21.

7. See Donnelly, cited in n. 6, above, p. 9.

8. Ibid., p. 43.

9. See Michael W. Doyle, "Liberalism and World Politics," American Political Science Review, 80 (1983), pp. 1151-70.

10. Martin Wight, "Why Is There No International Theory?," International Theory: Critical Investigations, ed. James Der Derian (London: MacMillan, 1995), p. 33.

11. Realpolitik has much in common with the practice of raison d'état in the eighteenth century. It denotes politics based on force, reliance on naked power, ruthlessness and fraud. Moral considerations are excluded for the sake of geopolitical and strategic gain. Power dictates what is just. The term was coined by Ludwig von Rochau in Gründsatze der Realpolitik (1853).

12. See Raymond Aron, Peace and War: A Theory of International Relations, trans. Richard Howard and Annette Baker Fox (New York: Doubleday, 1966), especially ch. 19; Hans Morgenthau, Politics among Nations: The Struggle for Power and Peace, 2nd ed'n. (New York: Alfred A. Knopf, 1956), ch. 1; Reinhold Niebuhr, Moral Man and Immoral Society; A Study in Ethics and Politics (New York: Charles Scribner's Sons, 1932).

13. Mary Frances Williams, Ethics in Thucydides: The Ancient Simplicity (Lanham, MD: University Press of America, 1998), pp. 24-25.

14. See Steven Forde, "Power and Morality in Thucydides," Thucydides' Theory of International Relations, ed. Lowell S. Gustafson (Baton Rouge, LA: Louisiana State University Press, 2000), pp. 151-73.

15. Aron, cited in no. 12, above, p. 599.

16. Williams, cited in n. 12, above, p. 41.

17. Toynbee writes the French "had lent themselves to militarism for 376 years (A.D. 1494-1870), till they had been cured of it by a crushing German retort. A Swedish militarism that had been rampant since Gustavus Adolphus (regnabat A.D. 1611-32) had disembarked his expeditionary force on German soil on 27-28 June 1630, had been extinguished by a subsequent and consequent Swedish experience of being bled white by 
Charles XII (regnabat A.D. 1697-1718). A Spanish militarism that had been coeval with its French counterpart had evaporated after the Thirty Years War. . . . Spanish, Swedish, French hearts had been changed, sooner or later, by the experience of learning through suffering; and since A.D. 1914 the Germans had received, in this punishment for a repeated sin, a double measure of this sovereign spiritual education." See Arnold J. Toynbee, $A$ Study of History, vol. 9 (Oxford: Oxford University Press, 1954), pp. 499-500. 